\title{
Do gaming motives mediate between psychiatric symptoms and problematic gaming? An empirical survey study
}

Running title: Gaming motives and psychiatric symptoms in problematic gaming

\begin{abstract}
Previous research has suggested that motives play an important role in several potentially addictive activities including online gaming. The aims of the present study were to (i) examine the mediation effect of different online gaming motives between psychiatric distress and problematic online gaming, and (ii) validate Italian versions of the Problematic Online Gaming Questionnaire, and the Motives for Online Gaming Questionnaire. Data collection took place online and targeted Italian-speaking online gamers active on popular Italian gaming forums, and/or Italian groups related to online games on social networking sites. The final sample size comprised 327 participants (mean age 23.1 years [SD=7.0], 83.7\% male). The two instruments showed good psychometric properties in the Italian sample. General psychiatric distress had both a significant direct effect on problematic online gaming and a significant indirect effect via two motives: escape and fantasy. Psychiatric symptoms are both directly and indirectly associated with problematic online gaming. Playing online games to escape and to avoid everyday problems appears to be a motivation associated with psychiatric distress and in predicting problematic gaming.
\end{abstract}

Keywords: video gaming; gaming motivation; problematic gaming use; internet gaming disorder (IGD); gaming addiction; mediation analysis

Word count: 4394 words without reference and appendices 


\section{Introduction}

In contemporary society, video gaming is one of the most popular leisure time activities, especially among youth. Given that this activity can be time-consuming, it may compete with traditional leisure time activities such as sports. Academic interest in both the positive and negative effects of gaming has increased substantially over the past two decades (Griffiths \& Pontes, 2015). The positive effects of gaming include cognitive skill enhancement such as faster and more accurate attention allocation (Granic, Lobel \& Engels, 2014) and increased problem-solving skills (Prensky, 2012), as well as social skill enhancement including learning social skills or prosocial behaviour (Ewoldsen et al., 2012; Gentile et al., 2009; Granic et al., 2014; Ng \& Wiemer-Hastings, 2005). There is also a large literature showing that the playing of videogames can be used therapeutically in medical treatments where gaming is used as a cognitive distractor to alleviate pain (Griffiths, Kuss \& Ortiz de Gortari, 2013). The negative effects of playing videogames include increased aggressive behaviour as a consequence of playing violent games (e.g., Anderson \& Bushman, 2001; Kutner \& Olson, 2008) and excessive playing causing functional and/or psychological impairment leading in a small minority of cases to problematic gaming and gaming addiction (e.g., Király, Nagygyörgy, Griffiths \& Demetrovics, 2014).

Research in the area of problematic gaming has led to the inclusion of "Internet Gaming Disorder" (IGD) as a condition warranting more clinical research, in the Appendix of the latest (fifth) edition of the Diagnostic and Statistical Manual of Mental Disorders(DSM5) (American Psychiatric Association [APA], 2013). At present, there is no consensus on IGD criteria, definition, and conceptualization (Brus, 2013; Hellman et al., 2012; KardefeltWinther, 2014a; Király, Griffiths \& Demetrovics, 2015; Griffiths et al., 2016). Until a consensus is reached, the present authors prefer to refer to the condition as problematic online gaming in the present paper. Several studies have examined the relationship between 
problematic online gaming and mental health, especially psychological distress (e.g., Kim et al., 2016; King \& Delfabbro, 2016; Son et al., 2013). Empirical studies have demonstrated that problematic online gaming has been associated with depression (Andreassen et al., 2016; Brunborg et al., 2014; Liau et al., 2015; Männikkö et al., 2015, Mentzoni et al., 2011; Peng \& Liu, 2010; Van Rooij et al., 2014; Wei et al., 2012), anxiety (Andreassen et al., 2016; Männikkö et al., 2015; Mentzoni et al., 2011), and social anxiety (Van Rooij et al., 2014; Walther et al., 2012; Wei et al., 2012). However, negative outcomes of excessive gaming affect only a minority of online gamers. Time spent playing online is not the only predictor for the development of problematic online gaming (Kuss et al., 2012; Lee \& Kim, 2017), in fact, it is much less related to it than assumed previously (Demetrovics \& Király, 2016; Griffiths, 2010; Király et al., 2017).

Studies have shed light on the importance of motivations in playing online games and on the prediction of problematic and addictive use of online games (e.g., Fuster et al., 2012; Kahn et al., 2015; Lee, Lee \& Choi, 2012; Yee, 2006). Escapism (i.e., the motive to play to avoid real life difficulties) has shown a strong association with problematic online gaming (e.g., Kuss et al., 2012; Kwon et al., 2011; Nagygyörgy et al., 2012; Yee, 2006; Zanetta Dauriat et al., 2011). Other motivations that are predictive of problematic online gaming include immersion (Billieux et al., 2011; Kneer \& Rieger, 2015), and achievement and/or advancement, related to the urge of progressing and improving within the game (Nagygyörgy et al., 2012; Yee, 2006; Zanetta Dauriat et al., 2011). However, social motives such as playing online to meet new people or to maintain existing friendships are predictive of more positive outcomes of online gaming (e.g., Cole \& Griffiths, 2007; Yang \& Liu, 2017).

In relation to various substance- and non-substance-related addictive disorders, motives not only correlate with problematic behaviours but can also be mediators in the relationship between psychiatric symptoms and substance use disorders. For example, the 
influence of motivations is present in the relationship between psychiatric symptoms and alcohol abuse. More specifically, studies have found a mediation role of coping motivation between symptoms such as anxiety and depression, and alcohol abuse (Cooper et al.,1995; Kaysen et al., 2007; Mason et al., 2014, Stewart et al., 2001). Furthermore, motivation to escape or dissociate have been found to mediate the association between aversive psychological and emotional states and gambling severity (Gupta \& Derevensky, 1998; Wood \& Griffiths, 2007). Another study examining gambling found a significant indirect effect of depressive symptoms on gambling-related problems and days gambled through coping motivation and gambling refusal self-efficacy (Takamatsu et al., 2015). Preliminary findings also suggest a mediating role of motivational factors in other behavioural addictions such as Internet addiction (Bischof-Kastner et al., 2014).

More recently, the importance of the motives as mediating factors has also been studied in problematic online gaming. Király et al. (2015) developed a mediation model where psychiatric symptoms explained problematic online gaming use both directly and indirectly with the mediation of two motivational factors (i.e., escape and competition). The main goal of the present study was to investigate the mediation that different motives have in the relationship between psychiatric symptoms and problematic online gaming among Italian online gamers. Furthermore, considering the lack of validated Italian psychometric instruments assessing online gaming, motivations to play, and possible negative outcomes, an additional aim of the present study was to validate Italian versions of the Problematic Online Gaming Questionnaire (POGQ; Demetrovics et al., 2012) that assesses the level of problematic online gaming, and the Motives for Online Gaming Questionnaire (MOGQ; Demetrovics et al., 2011) that assesses motivations in online gaming.

\section{Methods}


An online survey comprising 176 questions was created and administered to Italian online gamers in the summer of 2013. The survey was promoted via major Italian gaming forums, and Italian groups related to online games on social networking sites. In the advertised post, gamers were asked to visit a different website in order to complete the online survey. The survey webpage was visited 797 times. A total of 664 gamers began the survey (83.3\%) and 417 answered at least at half of the questions (52.3\%). A total of 327 gamers completed all the scales needed for the analysis (41.0\% of all visitors).

\section{Measures}

Questions relating to general socio-demographic information (e.g., gender, age, marital status, level of education) along with gaming-related variables (e.g., weekly time played, type of online games played) were asked at the beginning of the online survey.

The motivations for online gaming were assessed using four different instruments. The first one, the Motives for Online Gaming Questionnaire (MOGQ; Demetrovics et al., 2011) comprises 27 items using a 5-point Likert scale, chosen because of its wide range coverage of online gaming motivations, specifically seven distinct motives. These are: (1) escape (avoidance of reality and real problems), (2) coping (improvement of mood or channelling of aggression), (3) fantasy (desire to experience things not workable in real life such as the experience of a new identity), (4) skill development (improving concentration, coordination and/or other personal skills), (5) recreation (playful and relaxing aspects of playing), (6) competition (experiencing sense of achievement in defeating opponents), and (7) social (all the motivations relating to knowing other gamers and/or playing with them). In order to evaluate the validity of the Italian version of the MOGQ, three other widely used motivational instruments were included in the online survey, each one covering motives for online gaming from a distinct perspective. The Online Gaming Motivation Scale (Yee, 2006) comprises 12 items assessing three motivations (achievement, social and immersion) using a 
5-point Likert scale. Cronbach's alpha was 0.86 , showing a good internal consistency of the scale in the present sample. The Gaming Motivation Scale (GAMS; Lafreniere et al., 2012) comprises 18 items assessing six motivations on a 6-point Likert scale. The six subscales are based on the Self Determination Theory (SDT; Deci \& Ryan, 1985) and include: external regulation, introjected regulation, identified regulation, integrated regulation, intrinsic motivation, and amotivation. Internal consistency of the scale in the present sample was good $(\alpha=0.89)$. The final motivational instrument was the Player Experience of Need Satisfaction (PENS; Ryan et al., 2006), based on the Cognitive Evaluation Theory (CET), and focuses on the intrinsic part of SDT (Deci \& Ryan, 1985). The instrument comprises 10 items assessing three basic human needs satisfied by online gaming activity (autonomy, competence, and presence) on a 7-point scale. The PENS also showed good internal consistency with a Cronbach's alpha of 0.87 in the present sample.

Problematic online gaming was assessed using the Problematic Online Gaming Questionnaire (POGQ; Demetrovics et al., 2012). The POGQ is an 18-item instrument using a 5-point Likert scale assessing the level of problematic online gaming usage. It was developed by reviewing previous instruments as well as a qualitative examination of gamingrelated problems provided by gamers. Previous studies have demonstrated that the POGQ has good psychometric properties in both adult (Demetrovics et al., 2012) and adolescent samples (Pápay et al., 2013). It assesses six aspects of problematic gaming: (1) preoccupation (daydreaming and obsessive thinking about the gaming activity), (2) overuse (elongating gaming and incapacity to control gaming limits), (3) immersion (losing track of time and dealing excessively with the game), (4) withdrawal (experiencing withdrawal symptoms when unable to play), (5) interpersonal conflict (conflict with one's environment due to excessive play), and (6) social isolation (damage caused to social relationships due to the preference of gaming over social activities). 
Psychiatric symptoms were assessed with the Brief Symptom Inventory (BSI; Derogatis, 1975) comprising 53 items on a 5-point Likert scale assessing nine symptoms: somatization, obsession-compulsive, interpersonal sensitivity, depression, anxiety, hostility, phobia, paranoia and psychoticism. The Global Severity Index (GSI) is the mean score of the 53 items and assesses the general level of psychiatric distress. Internal consistency in the present sample was excellent $(\alpha=0.97)$.

An instrument assessing problematic use of the internet was included to evaluate the correlation with problematic online gaming. This was the short form of the Problematic Internet Use Questionnaire (PIUQ-6; Demetrovics et al., 2008; Demetrovics et al., 2016). The instrument comprises 6 items assessing three variables (obsession, neglect and control disorder) on a 5-point Likert scale. Cronbach's alpha showed a moderate internal consistency $(\alpha=0.67)$ in the present sample.

All instruments were translated into Italian using the same procedure (Harkness et al., 2004). First, a version of the translation was made by the first author of the present study. Second, the Italian version was back-translated into English by an independent bi-lingual psychology scholar. Finally, the differences were discussed and agreed with the other authors of the present study.

\section{Statistical analysis}

Confirmatory factor analyses (CFA) were run to test the original factorial structures of the MOGQ and the POGQ. Since the scales were not normally distributed, maximum likelihood estimation robust to non-normality (MLR) was used for both CFAs. To test model

fit, multiple indices were used (i.e., $\chi^{2}$, CFI, TLI, RMSEA with its $90 \%$ CI, SRMR) and $\chi^{2}$ should not be significant. However, it is sensitive to large sample sizes, therefore other indices give more accurate results. The comparative fit index (CFI) and Tucker-Lewis fit 
index (TLI) should be both greater than 0.9 , while the root mean square error approximation (RMSEA) with its $90 \%$ confidence interval $(90 \% \mathrm{CI})$ and the standardized root mean square residuals (SRMR) should be both less than 0.08 for an adequate fit (Browne \& Cudeck, 1993; Kline, 2005). Validities of the two scales were tested correlating the scales with related variables. MOGQ subscales were correlated with subscales of the other motivation scales used. The POGQ was correlated with time spent playing, problematic internet use, and general distress level. To test direct and indirect effects (through gaming motives [MOGQ subscales]) of general distress (GSI) on problematic online gaming (POGQ), a structural regression analyses within structural equation modelling (SEM) was carried out. Descriptive analyses were run with SPSS 20.0 statistical package (IBM Corp., 2011) and SEM analyses were run with MPLUS 6.0 (Muthén \& Muthén, 1987-2007).

\section{Results}

\section{Sample characteristics}

Descriptive statistics of the sample $(N=327)$ are shown in Table 1. [Table 1 about here]

\section{Validation of the Problematic Online Gaming Questionnaire (POGQ)}

The original six-factor model of the POGQ was tested with confirmatory factor analysis (CFA) and the results showed an adequate fit to the data $\left(\chi^{2}=260.6, p<.001, \mathrm{df}=118\right.$; $\mathrm{CFI}=0.936 ; \mathrm{TLI}=0.918 ; \mathrm{RMSEA}=0.061[0.051-0.071] \mathrm{C}_{\text {fit }}>0.90 \mathrm{p}_{\text {close }}=.036$;

SRMR=0.052). The modification indices suggested that a few error covariances should have been introduced in the CFA model. The similar meaning of some items explains the need for the error covariances: Item 8 (How often do you lose track of time when gaming?) with Item 13 (How often do you feel time stops while gaming?), and Item 6 (How often do you fail to meet up with a friend because you were gaming?) with Item 16 (How often do you choose 
gaming over going out with someone?). Factor loadings, factor determinacies, internal consistency, means, standard deviations of the subscales, and correlations between the subscales are shown in Table 2. [Table 2 about here]

The criterion validity of the POGQ was tested by correlating the total POGQ score with the total number of hours played weekly by the players. The Pearson's correlation was significant with moderate effect size $(r=.40, p<.001)$. Convergent validity was tested with the Problematic Internet Use Questionnaire Short Form (PIUQ-6; Demetrovics et al., 2008; Demetrovics et al., 2016) and with the Global Severity Index (GSI; Derogatis, 1975). The POGQ showed a strong significant correlation with both the PIUQ-6 $(r=.68, p<.001)$ and with the GSI $(r=.51, p<.001)$.

\section{Validation of the Motives for Online Gaming Questionnaire (MOGQ)}

The original seven-factor solution of the MOGQ was tested with confirmatory factor analysis (CFA) and the results showed an adequate fit $\left(\chi^{2}=627.5, p<.001, \mathrm{df}=300 ; \mathrm{CFI}=0.922\right.$; $\mathrm{TLI}=0.909 ; \mathrm{RMSEA}=0.058$ [0.051-0.064] $\left.\mathrm{C}_{\text {fit }}>0.90 \mathrm{p}_{\text {close }}=.023 ; \mathrm{SRMR}=0.059\right)$. Based on the modification indices, error covariances were introduced into the CFA model. The items involved were similar in meaning and wording: Item 8 (...because I can meet many different people) with Item 1 (...because I can get to know new people), item 20 (...to be somebody else for a while), and Item 13 (...to feel as if I was somebody else), and item 25 (...because it reduces tension) with Item 11 (...because it helps me to get rid of stress). Factor loadings, factor determinacies, internal consistency, means, standard deviations of the subscales and correlations between the subscales are shown in Table 3. [Table 3 about here]

The convergent validity of the MOGQ was tested by correlating its factors and subscales with other motivational instruments of similar content. Each factor of the MOGQ was paired with one or more subscales from other motivational instruments. Paired subscales 
aim to evaluate the same construct, even if from different perspectives, and can even contain similar items. The social factor strongly correlated with the motivational subscale of the same name from the Online Gaming Motivation Scale $(r=.64, p<.001)$ and with relatedness from the Player Experience for Need Satisfaction (PENS) $(r=.51, p<.001)$. The escape factor correlated with introjected regulation from the Gaming Motivation Scale, which refers to the regulation of behaviours through internal pressures such as anxiety and guilt $(r=.49, p<.001)$. The competition factor was correlated with the Online Gaming Motivation Scale's achievement factor $(r=.50, p<.001)$, with competence from the PENS $(r=.51, p<.001)$, and with the GAMS's external regulation $(r=.47, p<.001)$. The skill development factor correlated with GAMS identified regulation because of the motivation to develop part of the self $(r=.65$, $p<.001)$. The immersion subscale from the Online Gaming Motivation Questionnaire was closely associated with the fantasy factor. In both cases, gamers aim to be immersed in the virtual world $(r=.52, p<.001)$. Two of the motivational factors from the MOGQ (i.e., coping and recreation) were operationalized for the first time when developing the MOGQ, and therefore were not compared with any other subscales.

\section{Mediation model}

Finally, the mediation model was tested. It was assumed that psychiatric distress (as measured by the GSI) would have both a direct and indirect effect (via the mediating effect of some of the online gaming motives) on problematic online gaming (as assessed by the summarized score of the POGQ). Gaming motives were assessed with the scores of the seven MOGQ subscales. All variables were introduced in the model as continuous observed variables. The resulting model is presented in Figure 1. Analyses showed that general psychiatric distress had a significant direct effect on problematic online gaming $(\beta=.38$, $p<.001)$. The GSI also showed a direct significant effect on three of the seven motivational factors of the MOGQ: escape $(\beta=.36, p<.001)$, coping $(\beta=.18, p<.001)$ and fantasy (standard 
effect $=.27, p<.001)$. Regarding the associations between the motivational factors and problematic use (POGQ), escape $(\beta=.23, p<0.001)$, fantasy $(\beta=.13, p<.001)$ and competition $(\beta=.20, p<.001)$ had weak to moderate associations with total score on the POGQ. Regarding the indirect effect between psychiatric symptoms and problematic gaming, two paths were significant: "psychiatric symptoms $\rightarrow$ escape $\rightarrow$ problematic gaming" $(\beta=.08, p<.01)$ and "psychiatric symptoms $\rightarrow$ fantasy $\rightarrow$ problematic gaming" $(\beta=.04, p<.05)$. The total indirect effect equalled a standardized effect size of $0.13(p<.001)$ accounting for $25.7 \%$ of the total effect. The full model explained $43 \%$ of the variance of the score of problematic online gaming use. [Figure 1 about here]

\section{Discussion}

The present study had two aims: (i) to evaluate the psychometric properties of the POGQ and the MOGQ among Italian online gamers, and (ii) to investigate the mediation of different gaming motives in the relationship between psychiatric symptoms and problematic online gaming among Italian online gamers. Overall, the analyses demonstrated good psychometric properties for both instruments (i.e., POGQ and MOGQ). The internal consistency of the POGQ was optimal, criterion and convergent validities were tested with correlations between the POGQ and weekly game time, PIUQ-6, and GSI, respectively. Similarly, the Italian version of the MOGQ also demonstrated good psychometric properties. In the case of the MOGQ, internal consistencies of the seven subscales were all appropriate. Convergent validity was confirmed with the correlations with subscales from other motivational questionnaires.

Results of the mediation model suggested that psychiatric symptoms were both directly and indirectly (via escape and fantasy motivations to play) associated with problematic online gaming. The mediator effect of the motives accounted for $25.7 \%$ of the total effect of the Global Severity Index on the Problematic Online Gaming Questionnaire. 
Playing online games to escape and to avoid everyday problems appeared to be a motivation associated with psychiatric distress and predicting problematic gaming. As highlighted earlier in the paper, escapism has been shown to be a predictor of problematic use in Massive Multiplayer Online Role Playing Games (MMORPGs) (Billieux et al., 2013; Kardefelt-Winther, 2014b; Nagygyörgy et al., 2012; Xu et al., 2012; Yee, 2006). Given that this game genre offers rich and detailed alternative worlds full of exciting opportunities and fun (Castronova, 2008), they are especially suitable for escapism. Therefore, the high rate of MMORPG players in the sample may have contributed to the association between escapism and problematic play. In addition, the finding that escapism was the strongest mediator between psychiatric distress and problematic gaming is in line with the results of a previous study (Király et al., 2015) and strengthens the applicability of the self-medication theory (Khantzian, 1985) in the behavioural addiction context and more particularly in the problematic online gaming field. More specifically, the self-medication theory is based on the idea that people use substances or act addictive behaviours to compensate psychiatric symptoms (Khantzian, 1985). Moreover, escapism was one of the nine criteria included in DSM-5 for Internet Gaming Disorder (APA, 2013).

The second mediator found in the model was fantasy. The association between this motive and psychiatric symptoms is also in line with previous studies. For instance, psychiatric symptoms were found significantly and strongly correlated with fantasy motives to play in online gaming in a previous study (Király et al., 2015). Furthermore, there is evidence that fantasy proneness in daily life - especially its dissociative component - is related to psychiatric symptoms (Klinger et al., 2009). On the other hand, the association between fantasy and problematic gaming is more controversial. In the aforementioned study (Király et al., 2015), no relationship was found between these two variables. However, problematic online leisure-time was associated with a higher rate of depersonalization and a loss of contact with reality in a representative survey of the German population (Beutel et al., 
2011). Moreover, the fantasy motive is about experimenting with new identities and living out new experiences in alternative virtual worlds (that are not possible in daily life). As such, this motive is strongly related to the motive of escapism (i.e., a correlation of .72, see Table 3) when these virtual worlds are used to avoid and forget about real life problems. This may somewhat explain the low but significant association between fantasy and problematic online gaming in the present sample. In addition, the high prevalence of (M)MORPG [(Massively) Multiplayer Online Role Playing Game] users in the sample (i.e., 69.4\%) may also contribute to the same relationship because the experiencing of new identities, roles, and activities is central in this game type (Beutel et al., 2011; Király, Nagygyörgy, Griffiths \& Demetrovics, 2014). It also appears that gamers whose psychiatric distress is high might also be using gaming to live their fantasies which in a minority of cases (e.g., if it becomes a replacement for real life fantasies and adventures) might increase the risk of problematic gaming. However, this reasoning needs further empirical confirmation.

Unlike a previous study (i.e., Király et al., 2015), competition was not a mediator between psychiatric symptoms and problematic gaming. However, it predicted problematic gaming directly $(\beta=.20, p<.001)$, suggesting a role of this motivation in gaming attitude and possible issues related to problematic use. Previous studies have reported that the highest level of competitiveness was found in the most committed gamers in comparison with casual players (Jansz \& Tanis, 2007) and that players who scored high on narcissism were motivated to play by self-enhancement via competition with others (Jin \& Igarashi, 2016).

Coping did not show a mediating effect in the model neither. This finding corroborates a previous study that differentiated between escape and coping (Demetrovics et al., 2011), helping to create two distinct motivational factors in the MOGQ. It would appear that coping and escape have different underlying mechanisms. More specifically, while playing to escape everyday problems may play a role in problematic usage, gaming may also 
be used as an adaptive coping strategy to alleviate stress and tension without leading to problematic usage. As expected, social, recreation, and skill development motives were not significantly related to psychiatric distress or problematic gaming. Therefore, these three motivations for playing do not appear to lead to negative forms of gaming usage that often feature in the mass media (Ferguson, 2007; Kumpel \& Haas, 2015).

Some limitations are worth mentioning regarding the data collected in the present study. First, since the participation to the questionnaire was voluntary, the participants were self-selecting. This impacts on the generalizability of the results to the entire Italian online gaming population (Khazaal, et al., 2014). Even if (M)MORPG was the most common genre of online games at the time of data collection, it is difficult to assess the effect of this game type alone because gamers typically play numerous game genres at the same time, therefore examining gaming motivations by a specific gaming genre category was not possible. Furthermore, data were self-reported, and as such, it was prone to specific biases (e.g., memory recall, social desirability). Another problem was the length of the survey. Since it was a relatively long questionnaire (i.e., 176 questions), a considerable number of participants did not complete the survey. Another limitation is that not all the instruments used to test the convergent validity of the MOGQ and the POGQ had validated Italian versions. The final important limitation is that causal relationships could not be drawn due to the cross-sectional design of the study. Future studies should be carried out longitudinally and with larger samples in order to confirm preliminary findings of the present study.

Despite its limitations, the present study has some merit not only for scholars but also for clinicians. In line with previous findings, these results shed light to the importance of gaming motives in both prevention and treatment. More specifically, playing online games for recreational, social, and skill development reasons appears to be unrelated with problematic engagement with online games or the development of related psychiatric 
symptoms and therefore should not worry clinicians or parents. Furthermore, playing to cope with daily stress, to release some tension through gaming also appears to be safe in terms of addiction-like gaming. However, competition, based on the wish to defeat others might increase the risk of developing a problematic behaviour. Similarly, escaping, trying to avoid real life problems through gaming, and fantasy (i.e., experiencing new experiences and living out alternative identities through the game) are motives found to be associated with problematic online gaming in the present study. In addition, escapism and fantasy are related to a higher presence of psychiatric symptoms. Clinicians should carefully examine the presence of these three motives in playing online videogames and set the intervention accordingly. Regarding prevention, the results suggest that gaming motives may play an important role in predicting the possibility to develop problematic gaming and therefore should be examined during screening, along with other factors, both on individual and group level. Moreover, prevention programs should be tailored to address the specific psychological shortcomings (e.g., low self-esteem, inability to adaptively cope with stress, etc.) that motives reveal.

\section{Acknowledgement}

Present work was supported by the Hungarian Scientific Research Fund (Grant number: 111938). The funding institution had any role in the study design, collection, analysis or interpretation of the data, writing the manuscript, or the decision to submit the paper for publication.

\section{Author Disclosure Statement}

No competing financial interests exist. 


\section{References}

American Psychiatric Association (2013). Diagnostic and Statistical Manual of Mental Disorders (5th ed.). Arlington, VA: American Psychiatric Association.

Anderson, C. A., \& Bushman, B. J. (2001). Effects of violent video games on aggressive behavior, aggressive cognition, aggressive affect, physiological arousal, and prosocial behavior: A meta-analytic review of the scientific literature. Psychological Science, 12(5), 353-359.

Andreassen, C. S., Billieux, J., Griffiths, M.D., Kuss, D. J., Demetrovics, Z., Mazzoni, E., \& Pallesen, S. (2016) The relationship between technological addictions and symptoms of psychiatric disorders: A large-scale cross-sectional study. Psychology of Addictive Behaviors, 30, 252-262.

Beutel M. E., Brähler, E., Glaesmer, H., Kuss, D.J., Wölfling, K., \& Müller, K. W. (2011). Regular and problematic leisure-time Internet use in the community: results from a German population-based survey. Cyberpsychology, Behavior, and Social Networking, 14(5), 291-6.

Billieux, J., Chanal, J., Khazaal, Y., Rochat, L., Gay, P., Zullino, D., \& Van der Linden, M.(2011). Psychological predictors of problematic involvement in massively multiplayer online role-playing games: illustration in a sample of male cybercafé players. Psychopathology, 44, 165-171.

Billieux, J., Van der Linden, M., Achab, S., Khazaal, Y., Paraskevopoulos, L., Zullino, D. \& Thorens, G. (2013).Why do you play World of Warcraft? An in-depth exploration of 
self-reported motivations to play online and in-game behaviours in the virtual world of Azeroth. Computers in Human Behavior, 29, 103-109.

Bischof-Kastner, C., Kuntsche, E., \& Wolstein, J. (2014). Identifying problematic Internet users: Development and validation of the Internet Motive Questionnaire for Adolescents (IMQ-A). Journal of Medical Internet Research, 16(10), e230.

Browne, M.V., \& Cudeck, R. (1992). Alternative ways of assessing model fit. Sociological Methods \& Research, 21, 230-252.

Brunborg, G. S., Mentzoni, R. A., \& Frøyland, L. R. (2014). Is video gaming, or video game addiction, associate with depression, academic achievement, heavy episodic drinking, or conduct problems? Journal of Behavioral Addiction, 3, 27-32.

Brus, A. (2013). A young people's perspective on computer game addiction. Addiction Research \& Theory, 21(5), 365-375.

Castronova, E. (2008). Exodus to the virtual world: How online fun is changing reality: Palgrave Macmillan.

Cole, H. \& Griffiths, M. D. (2007). Social interactions in Massively Multiplayer Online RolePlaying gamers. CyberPsychology and Behavior, 10, 575-583.

Cooper, M. L., Frone, M.R., Russell, M., \& Mudar, P. (1995). Drinking to regulate positive and negative emotions: a motivational model of alcohol use. Journal of Personality and Social Psychology, 69, 990-1005.

Deci, E. L., \& Ryan, R.M.(1985). Intrinsic motivation and self-determination in human behavior. New York: Plenum. 
Demetrovics, Z., Szeredi, B., \&Rozsa, S.(2008). The three-factor model of Internet addiction: the development of the Problematic Internet Use Questionnaire. Behavior Research Methods, 40, 563-574.

Demetrovics, Z., Urbán, R., Nagygyörgy, K., Farkas, J., Zilahy, D., Mervó, B., Reindl, A., Ágoston, C., Kertész, A., \& Harmath, E. (2011). Why do you play? The development of the motives for online gaming questionnaire (MOGQ). Behavior Research Methods, 43, 815-825.

Demetrovics, Z., Urbán, R., Nagygyörgy, K., Farkas, J., Griffiths, M. D., Pápay, O., Kökönyei, G., Felvinczi, K. \& Oláh, A. (2012). The development of the Problematic Online Gaming Questionnaire (POGQ). PLoS ONE, 7(5): e36417.

Demetrovics, Z., \& Király, O. (2016). Commentary on Baggio et al. 2016: Internet/gaming addiction is more than heavy use over time. Addiction, 111, 523-524.

Demetrovics, Z., Király O., Griffiths M. D., Farkas, J., Kökönyei, G., Elekes, Z., Domokos, T., Oláh, A., Urbán, R., 2016. Psychometric properties of the Problematic Internet Use Questionnaire Short-Form in a nationally representative sample of adolescents. 11(8): e0159409. doi:10.1371/journal. pone.0159409

Derogatis, L. R., (1975). Brief Symptom Inventory. Baltimore, MD: Clinical Psychometric Research.

Ewoldsen, D. R., Eno, C. A., Okdie, B. M., Velez, J. A., Guadagno, R. E., \& DeCoster, J. (2012). Effect of playing violent video games cooperatively or competitively on subsequent cooperative behavior. Cyberpsychology, Behavior, and Social Networking, 15(5), 277-280. 
Ferguson, C.J. (2007). The good, the bad and the ugly: A meta-analytic review of positive and negative effects of violent video games. Psychiatric Quarterly, 78(4), 309-316.

Fuster, H., Oberst, U., Griffiths, M. D., Carbonell, X., Chamarro, A.\& Talarn, A. (2012). Psychological motivation in online role-playing games: A study of Spanish World of Warcraft players. Anales de Psicologia, 28, 274-280.

Gentile, D. A., Anderson, C. A., Yukawa, S., Ihori, N., Saleem, M., Ming, L. K., . . Bushman, B. J. (2009). The effects of prosocial video games on prosocial behaviors: International evidence from correlational, longitudinal, and experimental studies. Personality and Social Psychology Bulletin, 35(6), 752-763.

Granic, I., Lobel, A., \& Engels, R. C. (2014). The benefits of playing video games. American Psychologist, 69(1), 66-78.

Griffiths, M. D. (2010). The role of context in online gaming excess and addiction: Some case study evidence. International Journal of Mental Health and Addiction, 8, 119125.

Griffiths, M. D., Kuss, D. J., \& Ortiz de Gortari, A. (2013). Videogames as therapy: A review of the medical and psychological literature. In Miranda I. M. \& Cruz-Cunha, M. M. (Eds.), Handbook of research on ICTs for healthcare and social services: Developments and applications (pp.43-68). Pennsylvania: IGI Global.

Griffiths, M. D., \& Pontes, H. M. (2015). Addiction and entertainment products. In Nakatsu, R., Ciancarini, P., \& M. Rauterberg, M. (Eds.), Handbook of Digital Games and Entertainment Technologies (pp.1-22). New York: Springer.

Griffiths, M. D., van Rooij, T., Kardefelt-Winther, D., Starcevic, V., Király, O., ... \& Demetrovics Z. (2016). Working towards an international consensus on criteria for 
assessing Internet Gaming Disorder: a critical commentary on Petry et al (2014). Addiction, 111(1), 167-175.

Gupta, R. \& Derevensky, J. L. (1998). An empirical examination of Jacobs' General Theory of Addictions: do adolescent gamblers fit the theory? Journal of Gambling Studies, 14(1), 17-49.

Harkness, J. A., Pennell, B. E., \& Schoua-Glusberg, A. (2004). Questionnaire translation and assessment. In Presser, S., Rothgeb, J., Couper, M., Lessler, J., Martin, E., Martin, J., \& Singer, E. (Eds.), Methods for testing and evaluating survey questionnaires (pp. 453-473). New York, NY: John Wiley \& Sons.

Hellman, M., Schoenmakers, T. M., Nordstrom, B. R., \& van Holst, R. J. (2012). Is there such a thing as online video game addiction? A cross-disciplinary review. Addiction Research \& Theory, 21(2),102-112.

Hussain, Z., Griffiths, M. D. (2009). The attitudes, feelings, and experiences of online gamers: A qualitative analysis. CyberPsychology \& Behavior, 12(6), 747-53

IBM (2011). SPSS Statistics for Windows, Version 20.0. IBM Corp, Armonk, NY.

Jansz, J., \& Tanis, M. (2007). Appeal of playing online First Person Shooter Games. CyberPsychology \& Behavior, 10(1), 133-6.

Jin, K., \& Igarashi, T. (2016). The effects of narcissism and self-esteem on immersion in social network games and massively multiplayer online role-playing games. Shinrigaku Kenkyu, 87(1), 1-11.

Kahn, A. S., Shen, C., Lu, L., Ratan, R. A., Coary, S., Hou, J., Meng, J., Osborn, J. C., Williams, D. (2015). The Trojan Player Typology: A cross-genre, cross-cultural, 
behaviorally validated scale of video game play motivations. Computers in Human Behavior, 49, 354-361.

Kardefelt-Winther, D. (2014a). A critical account of DSM-5 criteria for internet gaming disorder. Addiction Research \& Theory, 23(2), 93-98.

Kardefelt-Winther, D. (2014b). The moderating role of psychosocial well-being on the relationship between escapism and excessive online gaming. Computers in Human Behavior, 38, 68-74.

Kaysen, D., Dillworth, T.M., Simpson, T., Waldrop, A., Larimer, M.E., \& Resick, P. A. (2007). Domestic violence and alcohol use: trauma-related symptoms and motives for drinking. Addictive Behaviors, 32, 1272-83.

Khantzian, E. J. (1985). The self-medication hypothesis of addictive disorders: Focus on heroin and cocaine dependence. American Journal of Psychiatry, 142(11), 1259-64.

Khazaal, Y., van Singer, M., Chatton, A., Achab, S., Zullino, D., Rothen, S., Khan, R., Billieux, J., \& Thorens, G. (2014). Does self-selection affect samples' representativeness in online surveys? An investigation in online video game research. Journal of Medical Internet Research, 16(7), e164.

Kim, N. R., Hwang, S.S., Choi, J.S., Kim, D. J., Demetrovics, Z., .. \& Choi S.W. (2016). Characteristics and psychiatric symptoms of Internet gaming disorder among adults using self-reported DSM-5 criteria. Psychiatry Investigation, 13(1), 58-66.

King, D. L., \& Delfabbro P. H. (2016). The cognitive psychopathology of Internet gaming disorder in adolescence. Journal of Abnormal Child Psychology, 44(8), 1635-1645. 
Király, O., Griffiths, M. D., \& Demetrovics, Z. (2015). Internet gaming disorder and the DSM-5: Conceptualization, debates, and controversies. Current Addiction Reports, 2(3), 254-262.

Király, O., Nagygyörgy, K., Griffiths, M. D., \& Demetrovics, Z. (2014). Problematic online gaming. In K. Rosenberg \& L. Feder (Eds.), Behavioral addictions: Criteria, evidence and treatment (pp. 61-95). New York, NY: Elsevier.

Király, O., Tóth, D., Urbán, R., Demetrovics, Z., \& Maraz, A. (2017). Intense video gaming is not essentially problematic. Manuscript under review.

Király, O., Urbán, R., Griffiths, M. D., Ágoston, C., Nagygyörgy, K., Kökönyei, G., \& Demetrovics, Z. (2015). The mediating effect of gaming motivation between psychiatric symptoms and problematic online gaming: an online survey. Journal of Medical Internet Research, 17(4), e88.

Kline, R.B. (2005). Principles and practice of structural equation modeling (2nd ed.). New York, NY: Guilford Press.

Klinger, E., Henning, V. R., \& Janssen, J. M. (2009). Fantasy-proneness dimensionalized: Dissociative component is related to psychopathology, daydreaming as such is not. Journal of Research in Personality, 43, 506-510.

Kneer, J., \& Rieger, D. (2015). Problematic game play: The diagnostic value of playing motives, passion, and playing time in men. Behavioral Sciences, 5, 203-213.

Kümpel, A. S., \& Haas, A. (2015). Framing gaming. The effects of media frames on perceptions of game(r)s. Games and Culture, 11(7-8), 720-744. 
Kuss, D. J., Louws, J., \& Wiers, R.W. (2012). Online gaming addiction? Motives predict addictive play behavior in massively multiplayer online role-playing games. Cyberpsychology, Behavior, and Social Networking, 15, 480-485.

Kutner, L., \& Olson, C. (2008). Grand theft childhood: The surprising truth about violent video games and what parents can do. New York: Simon \& Schuster.

Kwon, J.H., Chung, C.S., \& Lee, J. (2011). The effects of escape from self and interpersonal relationship on the pathological use of Internet games. Community Mental Health Journal, 47, 113-121.

Lafreniere, M. A. K., Verner-Filion, J.,\& Vallerand, R. J. (2012). Development and validation of the Gaming Motivation Scale (GAMS). Personality and Individual Differences, 53, 827-831.

Lee, C., \& Kim, O. (2017). Predictors of online game addiction among Korean adolescents. Addiction Research \& Theory, 25(1), 58-66.

Lee, J., Lee, M., \& Choi, I. H. (2012). Social network games uncovered: Motivations and their attitudinal and behavioral outcomes. Cyberpsychology, Behavior, and Social Networking, 15(12), 643-648.

Liau, A. K., Choo, H., Li, D., Gentile, D. A., Sim, T., \& Khoo, A. (2015). Pathological videogaming among youth: A prospective study examining dynamic protective factors. Addiction Research \& Theory, 23(4), 301-308.

Männikkö, N., Billieux, J., \& Kääriäinen, M. (2015). Problematic digital gaming behavior and its relation to the psychological, social and physical health of Finnish adolescents and young adults. Journal of Behavioral Addictions, 4, 281-288. 
Mason, A. E., Boden, M. T., \& Cucciare, M. A. (2014). Prospective associations among approach coping, alcohol misuse and psychiatric symptoms among veterans receiving a brief alcohol intervention. Journal of Substance Abuse Treatment, 46, 553-560.

Mentzoni, R. A., Brunborg, G. S., Molde, H., Myrseth, H., Skouverøe, K. J., Hetland, J., \& Pallesen, S. (2011). Problematic video game use: Estimated prevalence and associations with mental and physical health. Cyberpsychology, Behavior, and Social Networking, 14, 591-596.

Muthén, L. K., \& Muthén, B. O. (1987-2007). Mplus: User's guide (5th ed.). Los Angeles, CA: Muthén \& Muthén.

Nagygyörgy, K., Mihalik, Á., \& Demetrovics, Z. (2012). Az online játékok pszichológiai vonatkozásai. [Psychological aspects of online games]. In Gabos, E. (Ed.), A média hatása a gyermekekre és fiatalokra [The influence of media on children and youth] (pp. 242-248). Budapest: Nemzetközi Gyermekmentő Szolgálat Magyar Egyesülete.

Ng, B., \& Wiemer-Hastings, P. (2005). Addiction to the internet and online gaming. CyberPsychology and Behavior, 8, 110-113.

Pápay, O., Urbán, R., Griffiths, M. D., Nagygyörgy, K., Farkas, J., Kökönyei, G., Felvinczi, K., Oláh, A., Elekes, Z., \& Demetrovics, Z. (2013). Psychometric properties of the Problematic Online Gaming Questionnaire Short-Form (POGQ-SF) and prevalence of problematic online gaming in a national sample of adolescents. Cyberpsychology, Behavior, and Social Networking, 16(5), 340-348.

Peng, W., \& Liu, M. (2010). Online gaming dependency: A preliminary study in China. Cyberpsychology, Behavior, and Social Networking, 13, 329-333. 
Prensky, M. (2012). From digital natives to digital wisdom: Hopeful essays for 21 st century learning. Thousand Oaks, CA: Corwin Press.

Ryan, R. M., Rigby, C. S., \& Przybylski, A. (2006). The motivational pull of video games: A self-determination theory approach. Motivation and Emotion, 30, 347-365.

Son, D. T., Yasuoka, J., Poudel, K. C., Otsuka, K., \& Jimba, M. (2013). Massively multiplayer online role-playing games (MMORPG): Association between its addiction, self-control and mental disorders among young people in Vietnam. International Journal of Social Psychiatry, 59, 570-577.

Stewart, S. H., Zvolensky, M. J., \& Eifert, G. H. (2001). Negative-reinforcement drinking motives mediate the relation between anxiety sensitivity and increased drinking behavior. Personality and Individual Differences, 31, 157-171.

Takamatsu, S. K., Martens, M. P., \& Arterberry, B. J. (2015). Depressive symptoms and gambling behavior: Mediating role of coping motivation and gambling refusal selfefficacy. Journal of Gambling Studies, 32(2), 535-546.

Van Rooij, A. J., Kuss, D. J., Griffiths, M. D., Shorter, G. W., Schoenmakers, M. T., \& Van de Mheen, D. (2014). The (co-)occurence of problematic video gaming, substance use, and psychosocial problems in adolescents. Journal of Behavioral Addiction, 3, $157-165$.

Walther, B., Morgenstern, M., \& Hanewinkel, R. (2012). Co-occurrence of addictive behaviors: personality factors related to substance use, gambling and computer gaming. European Addiction Research, 18, 167-174. 
Wei, H. T., Chen, M. H., Huang, P. C., \& Bai, Y. M. (2012). The association between online gaming, social phobia, and depression: An Internet survey. BMC Psychiatry, 12, 92.doi: 10.1186/1471-244X-12-92.

Wood, R. T. A. \& Griffiths, M.D. (2007). A qualitative investigation of problem gambling as an escape-based coping strategy. Psychology and Psychotherapy: Theory, Research and Practice, 80, 107-125.

Xu, Z., Turel, O., \& Yuan, Y. (2012). Online game addiction among adolescents: motivation and prevention factors. European Journal of Information Systems, 21, 321-340.

Yang, C. C., \& Liu, D. (2017). Motives matter: motives for playing Pokemon Go and implications for well-being. Cyberpsychology, Behavior, and Social Networking, $20(1), 52-57$.

Yee, N. (2006). Motivations for play in online games. CyberPsychology \& Behavior, 9, 772775.

Zanetta Dauriat, F., Zermatten, A., Billieux, J., Thorens, G., Bondolfi, G., Zullino, D., \& Khazaal, Y. (2011). Motivations to play specifically predict excessive involvement in massively multiplayer online role-playing games: Evidence from an online survey. European Addiction Research, 17, 185-189. 


\section{Appendix A - Problematic online gaming questionnaire (POGQ)}

Please read the statements below regarding online gaming. The questionnaire REFERS TO ONLINE

GAMES exclusively, but we use the expression 'game' in each statement for simplicity's sake. Please indicate on the scale from 1 to 5 to what extent, and how often, these statements apply to you

\begin{tabular}{|c|c|c|c|c|c|c|}
\hline & & never & seldom & occasionally & often & always \\
\hline 1. & $\begin{array}{l}\text { When you are not gaming, how often do you } \\
\text { think about playing a game or think about } \\
\text { how would it feel to play at that moment? }\end{array}$ & 1 & 2 & 3 & 4 & 5 \\
\hline 2. & $\begin{array}{l}\text { How often do you play longer than } \\
\text { originally planned? }\end{array}$ & 1 & 2 & 3 & 4 & 5 \\
\hline 3. & $\begin{array}{l}\text { How often do you feel depressed or irritable } \\
\text { when not gaming only for these feelings to } \\
\text { disappear when you start playing? }\end{array}$ & 1 & 2 & 3 & 4 & 5 \\
\hline 4. & $\begin{array}{l}\text { How often do you feel that you should } \\
\text { reduce the amount of time you spend } \\
\text { gaming? }\end{array}$ & 1 & 2 & 3 & 4 & 5 \\
\hline 5. & $\begin{array}{l}\text { How often do the people around you } \\
\text { complain that you are gaming too much? }\end{array}$ & 1 & 2 & 3 & 4 & 5 \\
\hline 6. & $\begin{array}{l}\text { How often do you fail to meet up with a } \\
\text { friend because you were gaming? }\end{array}$ & 1 & 2 & 3 & 4 & 5 \\
\hline 7. & How often do you daydream about gaming? & 1 & 2 & 3 & 4 & 5 \\
\hline 8. & $\begin{array}{l}\text { How often do you lose track of time when } \\
\text { gaming? }\end{array}$ & 1 & 2 & 3 & 4 & 5 \\
\hline 9. & $\begin{array}{l}\text { How often do you get irritable, restless or } \\
\text { anxious when you cannot play games as } \\
\text { much as you want? }\end{array}$ & 1 & 2 & 3 & 4 & 5 \\
\hline 10. & $\begin{array}{l}\text { How often do you unsuccessfully try to } \\
\text { reduce the time you spend on gaming? }\end{array}$ & 1 & 2 & 3 & 4 & 5 \\
\hline 11. & $\begin{array}{l}\text { How often do you argue with your parents } \\
\text { and/or your partner because of gaming? }\end{array}$ & 1 & 2 & 3 & 4 & 5 \\
\hline 12. & $\begin{array}{l}\text { How often do you neglect other activities } \\
\text { because you would rather game? }\end{array}$ & 1 & 2 & 3 & 4 & 5 \\
\hline 13. & $\begin{array}{l}\text { How often do you feel time stops while } \\
\text { gaming? }\end{array}$ & 1 & 2 & 3 & 4 & 5 \\
\hline 14. & $\begin{array}{l}\text { How often do you get restless or irritable if } \\
\text { you are unable to play games for a few } \\
\text { days? }\end{array}$ & 1 & 2 & 3 & 4 & 5 \\
\hline 15. & $\begin{array}{l}\text { How often do you feel that gaming causes } \\
\text { problems for you in your life? }\end{array}$ & 1 & 2 & 3 & 4 & 5 \\
\hline 16. & $\begin{array}{l}\text { How often do you choose gaming over } \\
\text { going out with someone? }\end{array}$ & 1 & 2 & 3 & 4 & 5 \\
\hline 17. & $\begin{array}{l}\text { How often are you so immersed in gaming } \\
\text { that you forget to eat? }\end{array}$ & 1 & 2 & 3 & 4 & 5 \\
\hline 18. & $\begin{array}{l}\text { How often do you get irritable or upset when } \\
\text { you cannot play? }\end{array}$ & 1 & 2 & 3 & 4 & 5 \\
\hline
\end{tabular}

\begin{tabular}{|c|c||c|c|c|c||}
\hline Preoccupation & Immersion & Withdrawal & Overuse & Interpersonal Conflicts & Social Isolation \\
\hline \hline $\mathbf{1 , 7}$ & $\mathbf{2 , 8 , 1 3 , 1 7}$ & $\mathbf{3 , 9 , 1 4 , 1 8}$ & $\mathbf{4 , 1 0 , 1 5}$ & $\mathbf{5 , 1 1}$ & $\mathbf{6 , 1 3 , 2 0 , 2 7}$ \\
\hline
\end{tabular}




\section{Problematic online gaming questionnaire - Italian version (POGQ-IT)}

Le seguenti domande si riferiscono alle abitudini nei giochi online. Indica su una scala da 1 a 5 quanto queste frasi descrivono le tue abitudini

\begin{tabular}{|c|c|c|c|c|c|c|}
\hline & & mai & raramente & a volte & spesso & sempre \\
\hline 1. & $\begin{array}{l}\text { Quando non stai giocando, quanto spesso } \\
\text { pensi a giocare o a come sarebbe poter } \\
\text { giocare in quel momento? }\end{array}$ & 1 & 2 & 3 & 4 & 5 \\
\hline 2. & $\begin{array}{l}\text { Quante volte ti capita di giocare più di } \\
\text { quanto avevi previsto all'inizio? }\end{array}$ & 1 & 2 & 3 & 4 & 5 \\
\hline 3. & $\begin{array}{l}\text { Quanto spesso ti senti depresso o irritabile se } \\
\text { non stai giocando, quando invece questi stati } \\
\text { d'animo passano iniziando a giocare? }\end{array}$ & 1 & 2 & 3 & 4 & 5 \\
\hline 4. & $\begin{array}{l}\text { Quanto spesso senti che dovresti ridurre il } \\
\text { tempo che passi giocando? }\end{array}$ & 1 & 2 & 3 & 4 & 5 \\
\hline 5. & $\begin{array}{l}\text { Quanto spesso le persone attorno a te si } \\
\text { lamentano del fatto che passi troppo tempo a } \\
\text { giocare? }\end{array}$ & 1 & 2 & 3 & 4 & 5 \\
\hline 6. & $\begin{array}{l}\text { Quanto spesso rinunci a incontrare un amico } \\
\text { per giocare o per continuare a giocare? }\end{array}$ & 1 & 2 & 3 & 4 & 5 \\
\hline 7. & Quanto spesso fantastichi sui giochi? & 1 & 2 & 3 & 4 & 5 \\
\hline 8. & $\begin{array}{l}\text { Quanto spesso perdi la cognizione del tempo } \\
\text { mentre stai giocando? }\end{array}$ & 1 & 2 & 3 & 4 & 5 \\
\hline 9. & $\begin{array}{l}\text { Quanto spesso diventi irritabile, agitato o } \\
\text { ansioso quando non puoi giocare quanto } \\
\text { vorresti? }\end{array}$ & 1 & 2 & 3 & 4 & 5 \\
\hline 10. & $\begin{array}{l}\text { Quanto spesso provi, senza successo, a } \\
\text { ridurre il tempo che passi giocando? }\end{array}$ & 1 & 2 & 3 & 4 & 5 \\
\hline 11. & $\begin{array}{l}\text { Quanto spesso litighi con i tuoi genitori e/o } \\
\text { con il/la partner per motivi riguardanti il } \\
\text { gioco? }\end{array}$ & 1 & 2 & 3 & 4 & 5 \\
\hline 12. & $\begin{array}{l}\text { Quanto spesso rifiuti altre attività perché } \\
\text { preferisci giocare? }\end{array}$ & 1 & 2 & 3 & 4 & 5 \\
\hline 13. & $\begin{array}{l}\text { Quanto spesso ti sembra che il tempo si } \\
\text { fermi mentre giochi? }\end{array}$ & 1 & 2 & 3 & 4 & 5 \\
\hline 14. & $\begin{array}{l}\text { Quanto spesso diventi agitato o irritabile se } \\
\text { non hai potuto giocare per qualche giorno? }\end{array}$ & 1 & 2 & 3 & 4 & 5 \\
\hline 15. & $\begin{array}{l}\text { Quanto spesso pensi che il giocare ti causi } \\
\text { problemi nella tua vita? }\end{array}$ & 1 & 2 & 3 & 4 & 5 \\
\hline 16. & $\begin{array}{l}\text { Quanto spesso scegli di giocare invece di } \\
\text { uscire con qualcuno? }\end{array}$ & 1 & 2 & 3 & 4 & 5 \\
\hline 17. & $\begin{array}{l}\text { Quante volte sei così immerso nel gioco da } \\
\text { dimenticarti di mangiare? }\end{array}$ & 1 & 2 & 3 & 4 & 5 \\
\hline 18. & $\begin{array}{l}\text { Quanto spesso diventi irritabile o turbato } \\
\text { quando non puoi giocare? }\end{array}$ & 1 & 2 & 3 & 4 & 5 \\
\hline
\end{tabular}




\section{Appendix B - Motives for online gaming questionnaire (MOGQ)}

Please indicate how often you play online games for the reasons listed below by circling the appropriate response - almost never/never (1), some of time (2), half of the time (3), most of the time (4), almost always/always (5). There is no right or wrong answer! We are only interested in your motives for gaming.

\begin{tabular}{|c|c|c|c|c|c|c|}
\hline & I play online games... & $\begin{array}{l}\text { almost } \\
\text { never/ } \\
\text { never }\end{array}$ & $\begin{array}{c}\text { some of } \\
\text { the } \\
\text { time }\end{array}$ & $\begin{array}{c}\text { half of } \\
\text { the } \\
\text { time }\end{array}$ & $\begin{array}{c}\text { most of } \\
\text { the } \\
\text { time }\end{array}$ & $\begin{array}{c}\text { almost } \\
\text { always/ } \\
\text { always }\end{array}$ \\
\hline 1. & ... because I can get to know new people & 1 & 2 & 3 & 4 & 5 \\
\hline 2. & $\begin{array}{l}\text {... because gaming helps me to forget about } \\
\text { daily hassles }\end{array}$ & 1 & 2 & 3 & 4 & 5 \\
\hline 3. & ... because I enjoy competing with others & 1 & 2 & 3 & 4 & 5 \\
\hline 4. & $\begin{array}{l}\ldots \text { because gaming helps me get into a } \\
\text { better mood }\end{array}$ & 1 & 2 & 3 & 4 & 5 \\
\hline 5. & ... because gaming sharpens my senses & 1 & 2 & 3 & 4 & 5 \\
\hline 6. & $\begin{array}{l}\ldots \text { because I can do things that I am unable } \\
\text { to do or I am not allowed to do in real life }\end{array}$ & 1 & 2 & 3 & 4 & 5 \\
\hline 7. & $\ldots$ for recreation & 1 & 2 & 3 & 4 & 5 \\
\hline 8. & $\begin{array}{l}\ldots \text { because I can meet many different } \\
\text { people }\end{array}$ & 1 & 2 & 3 & 4 & 5 \\
\hline 9. & ... because it makes me forget real life & 1 & 2 & 3 & 4 & 5 \\
\hline 10. & ... because I like to win & 1 & 2 & 3 & 4 & 5 \\
\hline 11. & $\ldots$ because it helps me get rid of stress & 1 & 2 & 3 & 4 & 5 \\
\hline 12. & ... because it improves my skills & 1 & 2 & 3 & 4 & 5 \\
\hline 13. & $\ldots$ to feel as if I was somebody else & 1 & 2 & 3 & 4 & 5 \\
\hline 14. & ... because it is entertaining & 1 & 2 & 3 & 4 & 5 \\
\hline 15. & ... because it is a good social experience & 1 & 2 & 3 & 4 & 5 \\
\hline 16. & ... because gaming helps me escape reality & 1 & 2 & 3 & 4 & 5 \\
\hline 17. & $\begin{array}{l}\ldots \text { because it is good to feel that I am better } \\
\text { than others }\end{array}$ & 1 & 2 & 3 & 4 & 5 \\
\hline 18. & $\begin{array}{l}\ldots \text { because it helps me channel my } \\
\text { aggression }\end{array}$ & 1 & 2 & 3 & 4 & 5 \\
\hline 19. & ... because it improves my concentration & 1 & 2 & 3 & 4 & 5 \\
\hline 20. & ...to be somebody else for a while & 1 & 2 & 3 & 4 & 5 \\
\hline 21. & ... because I enjoy gaming & 1 & 2 & 3 & 4 & 5 \\
\hline 22. & ... because gaming gives me company & 1 & 2 & 3 & 4 & 5 \\
\hline 23. & $\begin{array}{l}\ldots \text { to forget about unpleasant things or } \\
\text { offences }\end{array}$ & 1 & 2 & 3 & 4 & 5 \\
\hline 24. & $\ldots$ for the pleasure of defeating others & 1 & 2 & 3 & 4 & 5 \\
\hline 25. & ... because it reduces tension & 1 & 2 & 3 & 4 & 5 \\
\hline 26. & $\begin{array}{l}\ldots \text { because it improves my coordination } \\
\text { skills }\end{array}$ & 1 & 2 & 3 & 4 & 5 \\
\hline 27. & $\ldots$ because I can be in another world & 1 & 2 & 3 & 4 & 5 \\
\hline
\end{tabular}

\begin{tabular}{|c|c|c|c|c|c|c||}
\hline \hline Social & Escape & Competition & Coping & Skill Development & Fantasy & Recreation \\
\hline \hline $\mathbf{1 , 8 , 1 5 , 2 2}$ & $\mathbf{2 , 9 , 1 6 , 2 3}$ & $\mathbf{3 , 1 0 , 1 7 , 2 4}$ & $\mathbf{4 , 1 1 , 1 8 , 2 5}$ & $\mathbf{5 , 1 2 , 1 9 , 2 6}$ & $\mathbf{6 , 1 3 , 2 0 , 2 7}$ & $\mathbf{7 , 1 4 , 2 1}$ \\
\hline
\end{tabular}




\section{Motives for online gaming questionnaire - Italian version (MOGQ-IT)}

Indica quanto spesso giochi online per le ragioni elencate di seguito, indicando la risposta più appropriata - Quasi mai/mai (1), A volte (2), Metà delle volte (3), La maggior parte delle volte (4), Quasi sempre/sempre (5). Non ci sono risposte errate! Siamo solo interessati alla motivazione per cui giochi online

\begin{tabular}{|c|c|c|c|c|c|c|}
\hline & Gioco online... & $\begin{array}{c}\text { Quasi } \\
\text { mai/mai }\end{array}$ & $\begin{array}{c}\text { A } \\
\text { volte }\end{array}$ & $\begin{array}{l}\text { Metà } \\
\text { delle } \\
\text { volte }\end{array}$ & $\begin{array}{c}\text { La maggior } \\
\text { parte delle } \\
\text { volte }\end{array}$ & $\begin{array}{c}\text { Quasi } \\
\text { sempre/ } \\
\text { sempre }\end{array}$ \\
\hline 1. & $\begin{array}{l}\text {. perchè mi permette di arrivare a } \\
\text { conoscere nuove persone }\end{array}$ & 1 & 2 & 3 & 4 & 5 \\
\hline 2. & $\begin{array}{l}\text {.. perchè giocare mi aiuta a dimenticare } \mathrm{i} \\
\text { problemi quotidiani della vita }\end{array}$ & 1 & 2 & 3 & 4 & 5 \\
\hline 3. & ... perchè mi piace competere con gli altri & 1 & 2 & 3 & 4 & 5 \\
\hline 4. & ... perchè giocare migliora il mio umore & 1 & 2 & 3 & 4 & 5 \\
\hline 5. & $\ldots$ perchè giocare affina i miei sensi & 1 & 2 & 3 & 4 & 5 \\
\hline 6. & $\begin{array}{l}\text {.. perchè posso fare cose di cui non sono } \\
\text { capace o che mi sono vietate nella vita reale }\end{array}$ & 1 & 2 & 3 & 4 & 5 \\
\hline 7. & ... per svago & 1 & 2 & 3 & 4 & 5 \\
\hline 8. & ... perchè posso conoscere diverse persone & 1 & 2 & 3 & 4 & 5 \\
\hline 9. & ... perchè mi fa dimenticare la vita reale & 1 & 2 & 3 & 4 & 5 \\
\hline 10. & ... perchè mi piace vincere & 1 & 2 & 3 & 4 & 5 \\
\hline 11. & ... perchè mi aiuta a liberarmi dallo stress & 1 & 2 & 3 & 4 & 5 \\
\hline 12. & ... perchè aumenta le mie abilità & 1 & 2 & 3 & 4 & 5 \\
\hline 13. & $\begin{array}{l}\ldots \text { per sentirmi come se fossi un'altra } \\
\text { persona }\end{array}$ & 1 & 2 & 3 & 4 & 5 \\
\hline 14. & ... perchè mi intrattiene & 1 & 2 & 3 & 4 & 5 \\
\hline 15. & ... perchè è una buona esperienza sociale & 1 & 2 & 3 & 4 & 5 \\
\hline 16. & $\begin{array}{l}\text {.. perchè giocare mi aiuta ad evadere dalla } \\
\text { realtà }\end{array}$ & 1 & 2 & 3 & 4 & 5 \\
\hline 17. & ... perchè è bello sentirsi migliori degli altri & 1 & 2 & 3 & 4 & 5 \\
\hline 18. & $\begin{array}{l}\text {... perchè mi aiuta ad incanalare la mia } \\
\text { aggressività }\end{array}$ & 1 & 2 & 3 & 4 & 5 \\
\hline 19. & ... perchè migliora la mia concentrazione & 1 & 2 & 3 & 4 & 5 \\
\hline 20. & ... per essere qualcun altro per un po' & 1 & 2 & 3 & 4 & 5 \\
\hline 21. & ... perchè mi diverto a giocare & 1 & 2 & 3 & 4 & 5 \\
\hline 22. & ... perchè giocare mi fa avere compagnia & 1 & 2 & 3 & 4 & 5 \\
\hline 23. & $\begin{array}{l}\text {.. per dimenticare le cose spiacevoli o } \\
\text { offensive }\end{array}$ & 1 & 2 & 3 & 4 & 5 \\
\hline 24. & ... per il piacere di sconfiggere gli altri & 1 & 2 & 3 & 4 & 5 \\
\hline 25. & ... perchè giocare mi riduce lo stress & 1 & 2 & 3 & 4 & 5 \\
\hline 26. & ... perchè migliora la mia coordinazione & 1 & 2 & 3 & 4 & 5 \\
\hline 27. & ... perchè posso essere in un altro mondo & 1 & 2 & 3 & 4 & 5 \\
\hline
\end{tabular}

